(11 June, p 1615), and other tests for HIV may be applicable.

We obviously agree that zidovudine should be used with care in asymptomatic HIV infected patients. Some may conclude, however, that $\mathrm{Dr}$ Marks and Ms Curtis's implication is that if treatment is shown to be beneficial testing may be considered routine as it may then be argued that it is in the best interests of the patient. Even if benefits are shown, however, we consider that specific counselling and consent would still be required.

P MORGAN-CAPNER D N HUTCHINSON

Public Health Laboratory,

Preston Infirmary, Preston PR1 6PS

\section{Specialisms in general practice}

Although I do not disagree with Dr E Martin (23 July, p 288) in his argument that it is possible to give an excellent service in one aspect of care in the community and yet be a bad general practitioner, I think that there is another side to the argument that needs to be debated. If we compare genera practice with its hospital equivalents of general surgery and general medicine it is easy to see that specialisms have an important role in developing the more general art. We would not expect a general surgeon in a district hospital to be able to perform heart transplants, nor a general physician to be able to perform all of the complexities of modern endoscopy, but it is undoubtedly true that lessons for general surgery and general medicine will emerge from those who pursue these specialisms. I therefore contend that the same may apply in general practice and that those who are actively researching the so called specialisms in general practice are doing so to develop through experiment and endeavour lessons that may aid those pursuing normal general practice.

There are obviously risks in primary care if practitioners become too concerned with one particular area. I think, however, that it is essential that we consider carefully ways of improving care of chronic diseases in general practice to help this group of patients who form an increasing part of general practice.

K JONES

Aldermoor Health Centre,

Southampton SO1 6ST

\section{Referral to hospital: can we do better?}

Dr Marshall Marinker and colleagues (13 August, p 461) question the relation between rates of referral and rates of consultation and discuss what may be inferred from such data. Our research group in Aberdeen has recently developed a standardised form of core data for practice reports in which we define two rates of referral: firstly, the list size referral rate, expressed as the number of referrals for each 1000 patients on the list, and, secondly, the workload referral rate, expressed as the number of referrals for each 1000 consultations. We have used three sets of data-list size, number of referrals, and number of consultations -in different ways. The relation between the two referral rates is: list size referral rate $=$ workload referral rate $\times$ consultation rate. This relation implies that all the variables that affect consultation rates must also affect list size referral rates. If we accept that workload referral rates and consultation rates vary (perhaps for many reasons) the range in list size referral rates will be even greater as the effects of these two sets of variations are multiplied.

We suggest that the workload referral rate and the consultation rate should be looked at separately as they measure different aspects of a doctor's work. There is also less variation when these two indices are considered separately. This in turn should produce less apparent variation in the behaviour of doctors when considering referral rates with all their political and economic implications. We therefore suggest on both practical and theoretical grounds that the workload referral rate become accepted as the better measure for referral from general practice.

If patterns of referral by individual doctors are to be investigated the simplest measurement might be a doctor's yearly number of referrals.

F P HOWARTH J M MAITLAND

Department of General Practice, Foresterhill Health Centre, Aberdeen AB9 2AY

\section{DNA fingerprinting}

Drs Kevin A Hart and Martin Bobrow (13 August, p 439) outlined well the expanding applications of DNA fingerprinting. We would like to outline a further important use in analysing human cancer.

Minisatellite DNA probes have been used to detect somatic changes specific to tumours in some cancerous tissues, particularly those of gastrointestinal origin. ${ }^{1}$ These changes may provide a novel marker for the clonality of the tumour. This may be useful in detecting the progression of a tumour, particularly in tissue in which metastatic spread is suspected but only a small biopsy specimen is available-for example, from gastroscopy biopsy-and in cases in which the results of conventional histology are equivocal. Hopefully improved clarification of how far a tumour has spread might enable a better approach to the management of patients

F E COTTER

Imperial Cancer Research Fund Department of $S$ NASIPURI

Medical Oncology,

St Bartholomew's Hospital,

London $\mathrm{EC} 1 \mathrm{~A} 7 \mathrm{BE}$

1 Thein SL, Jeffreys AJ, Gool HC, et al. Detection of somatic changes in human cancer DNA by DNA fingerprint analysis. Brf Cancer 1987;55:353-6.

\section{Community care: Italian style}

The report "Community care: Italian style" (3 September, p 575) focused attention on the past 10 years of community oriented psychiatric care in Italy, which is useful in view of Britain's problems in adapting to the Griffiths style of community psychiatry. The report did not, however, mention any of the difficulties encountered in Italy. Instead a cheery picture of a group of happy and healthy ex-patients gathered around a fireside was published with the report. This ignores the sad reality currently experienced by many ex-patients in Italy: family stresses and suicides among expatients, growing numbers of homeless people, and expanding prison populations are often the fate of such patients.

It is now realised in Italy that Law 180 was passed too hastily and enforced before the "alternative structures" replacing the mental hospitals were properly functioning. How badly the system is malfunctioning is now a matter of fierce debate both within and outside Italy. ${ }^{1-4}$ As a result, what has been seen is a change in the Italian system back towards institutionalisation. The article on community care in Italy was followed by "No U turn on community care for the mentally ill," which raised the question of whether the government in this country was considering an about turn in British plans for community care. This seems to be what is being seen in Italy with an expansion of compulsory detention from seven to 30 days, the setting up of residential hospitals, and the regional coordination of services.

Department of Psychiatry,

St Mary's Hospital, London W2 1NY

1 Jones $\mathrm{K}$, Poletti A. Understanding the Italian experience. $\mathrm{Br} \mathcal{F}$ Psychiatry 1985;146:341-7.

2 Ramon S. Understanding the Italian experience. $\mathrm{Br} \mathcal{F}$ Psychiatry 1985;146:208-9.

3 Tansella $\mathrm{M}$. Misunderstanding the Italian experience. $\mathrm{Br} \mathrm{F}$ Psychiatry 1985;147:450-1.

4 Jones $\mathrm{K}$, Poletti $\mathrm{A}$. The Italian experience reconsidered. $\mathrm{Br} \mathcal{F}$ Psychiatry 1986;148: 144-50.

\section{Does wearing two pairs of gloves protect against skin contamination?}

In their paper on the wearing of two pairs of gloves by operating theatre staff $\mathrm{Dr} \mathrm{H}$ Matta and colleagues (3 September, p 597) describe how in $26 \%$ of cases discomfort or loss of sensitivity caused surgeons to remove the outer pair of gloves before the end of an operation. If, however, the inner pair of gloves is chosen a half size larger than the usual glove size (which is then worn as the outer pair) there is no discomfort. Furthermore, the problem of loss of sensitivity, which is greatest when handling fine suture material, may be reduced by carefully looking during manoeuvres such as tying knots, which are usually performed practically without looking because they depend on subtle tactile and proprioceptive information. With these measures only a little practice is required before a second pair of gloves goes virtually unnoticed during an operation.

NIGEL FIELDMAN

West Norwich Hospital,

Norwich NR2 3TU

\section{Battle of the bottle}

"Lynch mob"? Your reviewer's hyperbole (20-27 August, p 564) in referring to the antimilk marketing lobby would be passed over as a joke had you yourself not taken up the phrase in Editor's Choice. Dr Frank Hytten's review is a diatribe and his lack of objectivity is plain. It is sad that some doctors still fail to perceive that, as the social marketing expert Richard Manoff put it, the aim of milk marketing activity is to "obtain greater control of the food supply." Honourable? No doubt, if it is remembered that profit alone is the spur.

We hope that Dr Hytten and you, sir, will note that the "lynch mob" who wished to control the milk companies included Unicef and many doctors such as Dr Clavano of the Philippines, who appealed to her colleagues to "counter the milk companies' multimillion dollar campaigns with all the effort we can muster to return babies back to their mothers' breasts for survival and health."'

And sometimes the "backsliding Third World" does sort out its own problems. In Papua New Guinea severe malnutrition among the children of Port Moresby fell from $11 \%$ to $4 \%$ after a promotional campaign and a ban on over the counter sales of feeding bottles increased the incidence of breast feeding from $65 \%$ to $88 \%$. $^{2}$

Or maybe Dr Hytten's tongue was in his cheek all along, and he is a surrogate lyncher himself?

TONY WATERSTON

Newcastle General Hospital,

Newcastle upon Tyne NE4 6BE

DAVID MORLEY

Tropical Child Health Unit,

Institute of Child Health, London

1 Manoff RK. Curbing the market. In: Jelliffe DB, Jelliffe EFP, eds. Programmes to promote breastfeeding. Oxford: Oxford University Press, 1988.

2 Grant J. State of the world's children 1984. Geneva: Unicef, 1985. 